\title{
Comparative Effect of Organic and Conventional Farming Practices on Micronutrient Content in Different Textured Soils of Haryana, India
}

\author{
Hardeep Singh Sheoran ${ }^{1 *}$, V.K. Phogat ${ }^{1}$, Rita Dahiya ${ }^{1}$, Subha Dhull ${ }^{2}$ \\ and Ridham Kakar ${ }^{3}$ \\ ${ }^{1}$ Department of Soil Science, ${ }^{2}$ Department of Microbiology, CCS Haryana Agricultural \\ University, Hisar-125004, Haryana, India \\ ${ }^{3}$ Haryana Space Applications Center, CCS HAU Campus, Hisar-125004, Haryana, India \\ *Corresponding author
}

\section{A B S T R A C T}

\begin{tabular}{|c|}
\hline Keywords \\
\hline $\begin{array}{l}\text { Organic, } \\
\text { Conventional, } \\
\text { Micronutrient and } \\
\text { soil quality }\end{array}$ \\
\hline Article Info \\
\hline $\begin{array}{l}\text { Accepted: } \\
28 \text { March } 2018 \\
\text { Available Online: } \\
\text { 10 April } 2018\end{array}$ \\
\hline
\end{tabular}

\begin{abstract}
The present study was conducted to assess the effect of organic and conventional management practices on micronutrient content in different textured soils of Haryana. Fifty surface $(0-15 \mathrm{~cm})$ soil samples were collected from different villages located at 11 districts of Haryana. The texture of soil varied from sand to clay loam. The highest of content of all the micronutrient $(\mathrm{Zn}, \mathrm{Fe}, \mathrm{Cu}$ and $\mathrm{Mn}$ ) was recorded in clay loam soils while lowest in sand under both the farming systems. Organic farming resulted in significant increase in zinc content from 1.32 to $1.90 \mathrm{mg} \mathrm{kg}^{-1}$, iron content from 9.38 to $11.38 \mathrm{mg}$ $\mathrm{kg}^{-1}$, copper content from 1.19 to $1.28 \mathrm{mg} \mathrm{kg}^{-1}$ and $\mathrm{Mn}$ from 4.95 to $5.24 \mathrm{mg} \mathrm{kg}^{-1}$ over conventionally managed soils. Overall, the percent increase in $\mathrm{Zn}, \mathrm{Fe}, \mathrm{Cu}$ and $\mathrm{Mn}$ content of soils was of the order of 43.9, 21.3, 7.5 and $5.8 \%$, respectively, upon adoption of organic over conventional farming practices. Hence, it can be concluded from results of the study that organic farming sustains a higher micronutrient level in soils as compared to their counterparts and thereby sustaining the soil quality.
\end{abstract}

\section{Introduction}

The world's population currently stands at just over 6.7 billion and is projected to surpass 9 billion by 2050 (Human Development Report, 2016). Therefore, the key role of agriculture now and in future is to provide safe and quality food for ever growing population. It has been observed that from 1965 to 2015, population of the world has increased by $111 \%$ whereas crop production rose by $162 \%$
(Burney et al., 2010) and it is anticipated that further increase in production and productivity would only be possible through intensive use of land resources, irrigation, fertilizers, pesticides, modern machineries and advanced techniques and therefore conventional farming practices has an important role in improving food productivity to meet over increasing human demands. These intensive farming practices are causing the great pressure on natural resources resulting in degradation and 
depletion of soil, water, etc. Therefore, there are growing concerns about socio-economic and environmental adverse effects of chemical-dependent conventional farming system which led the scientists and researchers to seek alternative systems that may provide a sound basis to achieve the target of sustainable agriculture. Among alternative farming systems, organic farming has gained momentum worldwide and has expanded in the last decade because of environmental, economic and social concerns (Araujo et al., 2009). Organic agriculture is a holistic approach that does not use synthetic fertilizers and pesticides and attempt to close nutrient cycle on their farms, protect environmental quality and enhance beneficial biological interactions and processes (Vandermer et al., 1995). It is considered to be more environmentally sound than intensive farming practices, which is dependent on the routine use of agrochemicals for crop production (Bengtsson et al., 2005). Organic farming has the potential to arrest progressive degradation of soil health by restoring, maintaining, and enhancing natural processes and nutrient cycling in a given ecosystem. As it is a lowinput farming, fertilization is brought about by a strong reliance on closed on-farm nutrient cycling in organic farming systems. It is mediated by returning plant residues and manures from livestock back to the land, enhancing biological nitrogen fixation by legumes, and versatile crop rotations. Thus, organic farming could improve soil biological function and nutrient cycling and may help to reverse declining trends in soil fertility by improving the soil organic matter (SOM) status (Stockdale et al., 2001). Organic farming systems have been increasing with an annual growth rate of $26 \%$ and at present play a more and more important role in agriculture (Herencia et al., 2008a). Shifting from conventional to organic practices results in considerable changes in the soil properties and is thus likely to modify the processes that in turn affect the soil fertility. They may also affect the availability of nutrients to crops either directly by contributing to nutrient pools or indirectly by influencing the soil environment. Studies comparing the conventional and organic farming systems have shown an increase in soil organic matter (SOM) and nutrient contents in organically managed soils (Herencia et al., 2008b). Nevertheless, there is still inconsistent data on the effect of different management systems on soil properties particularly with respect to micronutrients status of soil. Some studies have compared conventional to organic farming systems, but the obtained results are often controversial because of the interactive effects of several farming practices, soil quality, crop varieties, time of harvesting etc. (Reganold et al., 2010). The real picture about overall sustainability of organic production systems, however, continues to face many challenges. Such concerns require greater understanding of the long-term effects of organic farming system and its feasibility as an alternative to the conventional practices, for sustainable use of natural resources. Keeping in view the above concerns, the present study has been planned to assess the effect of organic and conventional farming practices on soil micronutrients status of soils.

\section{Materials and Methods}

The materials and methods used to study the comparative effects of organic and conventional farming practices on micronutrient content in soil have been described and presented here as per details given below:

\section{Location}

Organic farms under different cropping systems, vegetables and horticultural crops and their adjoining conventional farms, were identified at eleven districts of Haryana, 
namely, Sirsa, Fatehabad, Hisar, Jind, Kaithal, Karnal, Kurukshetra, Ambala, Panchkula, Yamunanagar and Panipat and their soil properties were studied. Locations of sampling sites are presented in the Figure 1.

\section{Collection and processing of soil samples}

A total of 50 surface $(0-15 \mathrm{~cm})$ soil samples in triplicates were collected from organic as well as adjoining conventional farms and analysed for the micronutrient content in soil.

\section{Available (DTPA extractable) Zinc, Manganese, Copper and Iron}

DTPA extractable zinc, iron, copper and manganese were determined by the method given by Lindsay and Norvell (1978). DTPA, a chelating agent, extracts the easily soluble zinc, iron, copper and manganese by forming soluble complexes. The extracting solution is buffered at $\mathrm{pH} 7.3$ by triethanolamine (TEA) and also includes $\mathrm{CaCl}_{2}$ to prevent dissolution of $\mathrm{CaCO}_{3}$. These conditions permit the right amount of $\mathrm{Zn}, \mathrm{Fe}, \mathrm{Cu}$ and $\mathrm{Mn}$ to be extracted and $\mathrm{CaCl}_{2}$ to stabilize the $\mathrm{pH}$ of the extractant. The elements in the DTPA extract are determined by atomic absorption spectrophotometer (AAS). The critical limits used for micro nutrients in soils of Haryana are given in Table 1 .

\section{Statistical analysis}

The significance of treatment effects was analyzed using two factorial RBD analysis using OP Stat, CCS HAU Hisar, software.

\section{Results and Discussion}

A perusal of data on different nutrients in Table 2 and 3 indicated that conversion of conventional system of farming to organic farming exhibited significant increase in available zinc, iron, copper and manganese contents at different locations and largely increased with increase in clay content of soil i.e. $\mathrm{L}_{1}$ to $\mathrm{L}_{25}$. The maximum available zinc, iron, copper and manganese contents were observed in heavy textured soils i.e. clay loam while lowest in sand textured soil. The highest zinc content of $2.70 \mathrm{mg} \mathrm{kg}^{-1}$ was recorded in $\mathrm{L}_{24}$ (clay loam) and lowest $\left(0.49 \mathrm{mg} \mathrm{kg}^{-1}\right)$ in $\mathrm{L}_{1}$ (sand) in conventional farming system. The corresponding values increased to $3.88 \mathrm{mg}$ $\mathrm{kg}^{-1}$ and $0.88 \mathrm{mg} \mathrm{kg}^{-1}$ upon conversion to organic farming. There was a significantly higher zinc content $\left(1.90 \mathrm{mg} \mathrm{kg}{ }^{-1}\right)$ in organically managed soils than the conventionally managed soils $\left(1.32 \mathrm{mg} \mathrm{kg}^{-1}\right)$. Similarly, organic farming exerted a significant influence on the availability of iron in soils (Table 3).

Organic farming resulted in significant increase in iron content from 9.38 to $11.38 \mathrm{mg}$ $\mathrm{kg}^{-1}$, copper content from 1.19 to $1.28 \mathrm{mg} \mathrm{kg}^{-1}$ and $\mathrm{Mn}$ from 4.95 to $5.24 \mathrm{mg} \mathrm{kg}^{-1}$. There was a large variation in zinc, iron copper and manganese contents at different locations. The contents of these nutrients, however, largely increased with increase in clay content of soils in both conventionally and organic farming systems. Further, interaction effect between farming system and locations on micronutrients in soils was also found significant. The percent increase in $\mathrm{Zn}, \mathrm{Fe}, \mathrm{Cu}$ and $\mathrm{Mn}$ content in soils were 43.9, 21.3, 7.5 and $5.8 \%$, respectively, upon conversion to organic over conventional farming. The spatial variability maps for micronutrients have been also prepared and are presented in figures 2-5.

Organic farming found to increase available macro and micro nutrient at locations varying in soil texture. The maximum available micro nutrient was observed in clay loam soil while lowest in sand. Greater availability of available micro nutrient associated with the organic farming has commonly been reported which is closely related to SOM build up (Mantovi et al., 2003; Bulluck et al., 2002). 
Table.1 Critical limits of DTPA extractable $\mathrm{Zn}, \mathrm{Cu}, \mathrm{Fe}$ and $\mathrm{Mn}$ in soils of Haryana

\begin{tabular}{|l|c|c|c|c|}
\hline \multirow{2}{*}{ Parameter $(\mathrm{mg} / \mathrm{kg})$} & \multicolumn{4}{|c|}{ Category } \\
\cline { 2 - 5 } & Low & Moderate & Sufficient & High \\
\hline DTPA extractable Zn & $<0.6$ & $0.6-1.2$ & $1.2-2.4$ & $>2.4$ \\
\hline DTPA extractable Cu & $<0.2$ & $0.2-0.4$ & $0.4-0.8$ & $>0.8$ \\
\hline DTPA extractable Fe & $<4.5$ & $4.5-9.0$ & $9.0-18.0$ & $>18.0$ \\
\hline DTPA extractable Mn & $<2.5$ & $2.5-3.5$ & $3.5-7.0$ & $>7.0$ \\
\hline
\end{tabular}

Table.2 Zinc and iron (ppm) concentration in soils under conventional and organic farming systems at different locations

\begin{tabular}{|c|c|c|c|c|c|c|}
\hline \multirow{2}{*}{$\begin{array}{l}\text { Location } \\
\text { (L) }\end{array}$} & \multicolumn{3}{|c|}{ Zinc(Zn) } & \multicolumn{3}{|c|}{ Iron (Fe) } \\
\hline & Conventional & Organic & Mean & Conventional & Organic & Mean \\
\hline $\mathbf{L}_{1}$ & 0.49 & 0.58 & 0.54 & 2.67 & 2.52 & 2.60 \\
\hline $\mathbf{L}_{2}$ & 0.65 & 0.58 & 0.62 & 4.02 & 3.81 & 3.92 \\
\hline $\mathbf{L}_{3}$ & 0.70 & 0.86 & 0.78 & 8.36 & 10.60 & 9.48 \\
\hline $\mathbf{L}_{4}$ & 1.74 & 2.06 & 1.90 & 10.12 & 15.72 & 12.92 \\
\hline $\mathbf{L}_{5}$ & 2.04 & 2.14 & 2.09 & 5.16 & 6.82 & 5.99 \\
\hline $\mathbf{L}_{6}$ & 1.31 & 2.14 & 1.73 & 2.88 & 2.54 & 2.71 \\
\hline $\mathbf{L}_{7}$ & 0.57 & 1.63 & 1.10 & 10.18 & 13.23 & 11.71 \\
\hline $\mathbf{L}_{8}$ & 3.12 & 3.57 & 3.35 & 2.78 & 2.26 & 2.52 \\
\hline $\mathrm{Lg}_{9}$ & 0.96 & 1.28 & 1.12 & 6.82 & 9.88 & 8.35 \\
\hline$\overline{\mathbf{L}_{10}}$ & 1.56 & 1.94 & 1.75 & 13.26 & 15.98 & 14.62 \\
\hline $\mathbf{L}_{11}$ & 0.80 & 1.02 & 0.91 & 8.76 & 9.16 & 8.96 \\
\hline $\mathbf{L}_{12}$ & 1.36 & 2.71 & 2.04 & 11.72 & 15.63 & 13.68 \\
\hline $\mathbf{L}_{13}$ & 1.10 & 1.66 & 1.38 & 6.81 & 9.66 & 8.24 \\
\hline $\mathbf{L}_{14}$ & 1.26 & 1.92 & 1.59 & 9.23 & 12.04 & 10.64 \\
\hline $\mathbf{L}_{15}$ & 2.04 & 2.77 & 2.41 & 15.34 & 19.56 & 17.45 \\
\hline$\overline{\mathbf{L}_{16}}$ & 1.02 & 1.62 & 1.32 & 14.68 & 20.48 & 17.58 \\
\hline $\mathbf{L}_{17}$ & 1.79 & 2.89 & 2.34 & 13.45 & 16.59 & 15.80 \\
\hline $\mathbf{L}_{18}$ & 0.59 & 1.58 & 1.09 & 15.02 & 16.28 & 15.82 \\
\hline $\mathbf{L}_{19}$ & 0.98 & 1.38 & 1.18 & 12.14 & 11.57 & 11.86 \\
\hline $\mathbf{L}_{20}$ & 0.72 & 1.42 & 1.07 & 7.18 & 6.86 & 7.02 \\
\hline $\mathbf{L}_{21}$ & 1.92 & 3.40 & 2.66 & 9.57 & 10.42 & 10.00 \\
\hline $\mathbf{L}_{22}$ & 0.61 & 0.78 & 0.70 & 8.32 & 10.23 & 9.28 \\
\hline $\mathbf{L}_{23}$ & 0.90 & 1.21 & 1.06 & 9.18 & 11.24 & 10.21 \\
\hline $\mathbf{L}_{24}$ & 2.70 & 3.88 & 3.29 & 11.58 & 13.23 & 12.41 \\
\hline $\mathbf{L}_{25}$ & 2.03 & 2.54 & 2.29 & 15.36 & 18.14 & 15.81 \\
\hline Mean & 1.32 & 1.90 & & 9.38 & 11.38 & \\
\hline CD at $5 \%$ & \multicolumn{3}{|c|}{$\begin{array}{l}\text { Location }(\mathrm{L})=0.11, \\
\text { Farming system }(\mathrm{F})=0.03, \mathrm{~L} \times \mathrm{F}= \\
0.16\end{array}$} & \multicolumn{3}{|c|}{$\begin{array}{l}\text { Location }(\mathrm{L})=0.65 \\
\text { Farming system }(\mathrm{F})=0.18, \mathrm{~L} \text { x } \mathrm{F}= \\
0.92\end{array}$} \\
\hline
\end{tabular}


Table.3 Copper and Manganese (ppm) concentration in soils under conventional and organic farming systems at different locations

\begin{tabular}{|c|c|c|c|c|c|c|}
\hline \multirow{2}{*}{$\begin{array}{l}\text { Location } \\
\text { (L) }\end{array}$} & \multicolumn{3}{|c|}{ Copper $(\mathbf{C u})$} & \multicolumn{3}{|c|}{ Manganese (Mn) } \\
\hline & Conventional & Organic & Mean & Conventional & Organic & Mean \\
\hline $\mathbf{L}_{1}$ & 0.45 & 0.23 & 0.34 & 3.06 & 2.43 & 2.75 \\
\hline $\mathrm{L}_{2}$ & 0.21 & 0.29 & 0.25 & 2.92 & 2.94 & 2.93 \\
\hline$\overline{\mathbf{L}_{3}}$ & 1.02 & 1.19 & 1.11 & 3.62 & 4.22 & 3.92 \\
\hline $\mathbf{L}_{4}$ & 1.28 & 1.02 & 1.15 & 5.62 & 5.62 & 5.62 \\
\hline $\mathbf{L}_{5}$ & 0.62 & 0.76 & 0.69 & 3.67 & 3.78 & 3.73 \\
\hline $\mathrm{L}_{6}$ & 0.89 & 1.26 & 1.08 & 5.22 & 4.50 & 4.86 \\
\hline $\mathrm{L}_{7}$ & 0.72 & 0.68 & 0.70 & 4.84 & 5.78 & 5.31 \\
\hline $\mathbf{L}_{8}$ & 0.58 & 0.78 & 0.68 & 3.67 & 3.42 & 3.55 \\
\hline $\mathrm{L}_{9}$ & 0.66 & 0.56 & 0.61 & 5.12 & 4.34 & 4.73 \\
\hline $\mathbf{L}_{10}$ & 1.64 & 1.52 & 1.58 & 4.59 & 6.46 & 5.53 \\
\hline $\mathbf{L}_{11}$ & 1.22 & 1.46 & 1.34 & 5.90 & 6.84 & 6.37 \\
\hline $\mathrm{L}_{12}$ & 1.98 & 2.04 & 2.01 & 5.78 & 6.12 & 5.95 \\
\hline $\mathbf{L}_{13}$ & 1.39 & 1.56 & 1.48 & 5.10 & 4.70 & 4.90 \\
\hline $\mathrm{L}_{14}$ & 1.50 & 1.49 & 1.50 & 5.32 & 5.72 & 5.52 \\
\hline $\mathbf{L}_{15}$ & 1.37 & 1.55 & 1.46 & 3.22 & 3.46 & 3.34 \\
\hline $\mathrm{L}_{16}$ & 1.50 & 1.56 & 1.53 & 5.62 & 5.88 & 5.75 \\
\hline $\mathbf{L}_{17}$ & 1.02 & 1.34 & 1.18 & 5.40 & 5.24 & 5.32 \\
\hline $\mathbf{L}_{18}$ & 1.88 & 1.93 & 1.91 & 5.69 & 6.89 & 6.29 \\
\hline $\mathbf{L}_{19}$ & 1.78 & 1.63 & 2.13 & 5.12 & 4.77 & 4.95 \\
\hline $\mathbf{L}_{20}$ & 0.56 & 0.85 & 0.71 & 4.80 & 4.30 & 4.55 \\
\hline $\mathbf{L}_{21}$ & 1.06 & 1.28 & 1.17 & 4.89 & 5.22 & 5.06 \\
\hline $\mathrm{L}_{22}$ & 1.20 & 1.33 & 1.27 & 5.60 & 7.12 & 6.36 \\
\hline $\mathbf{L}_{23}$ & 1.46 & 1.35 & 1.41 & 5.98 & 8.06 & 7.02 \\
\hline $\mathbf{L}_{24}$ & 1.79 & 2.12 & 1.96 & 6.67 & 7.48 & 7.08 \\
\hline $\mathrm{L}_{25}$ & 1.98 & 2.28 & 1.71 & 6.36 & 5.68 & 6.02 \\
\hline Mean & 1.19 & 1.28 & & 4.95 & 5.24 & \\
\hline CD at $5 \%$ & \multicolumn{3}{|c|}{$\begin{array}{l}\text { Location }(\mathrm{L})=0.07 \text {, } \\
\text { Farming system }(\mathrm{F})=0.02, \mathrm{~L} \times \mathrm{F}=0.10\end{array}$} & \multicolumn{3}{|c|}{$\begin{array}{l}\text { Location }(\mathrm{L})=0.17 \text {, } \\
\text { Farming system }(\mathrm{F})=0.4, \mathrm{~L} \times \mathrm{F}=0.24\end{array}$} \\
\hline
\end{tabular}

Fig.1 Sampling sites in selected districts of Haryana

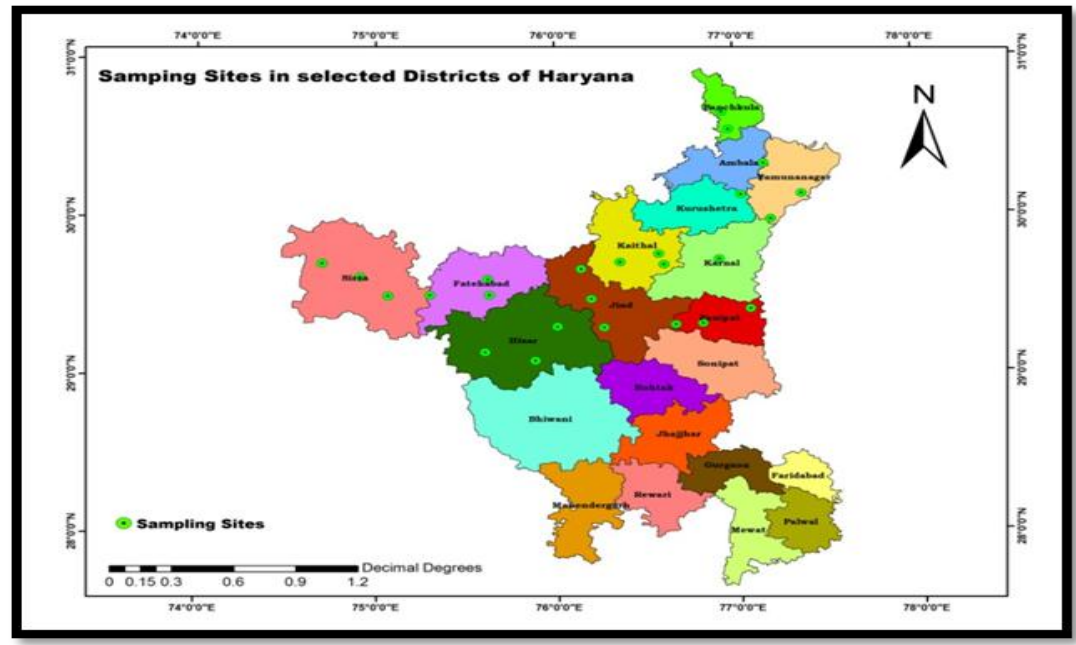


Fig.2 The spatial variability map of $\mathrm{Zn}$ concentration in soils under organic and conventional farming systems at different locations of Haryana
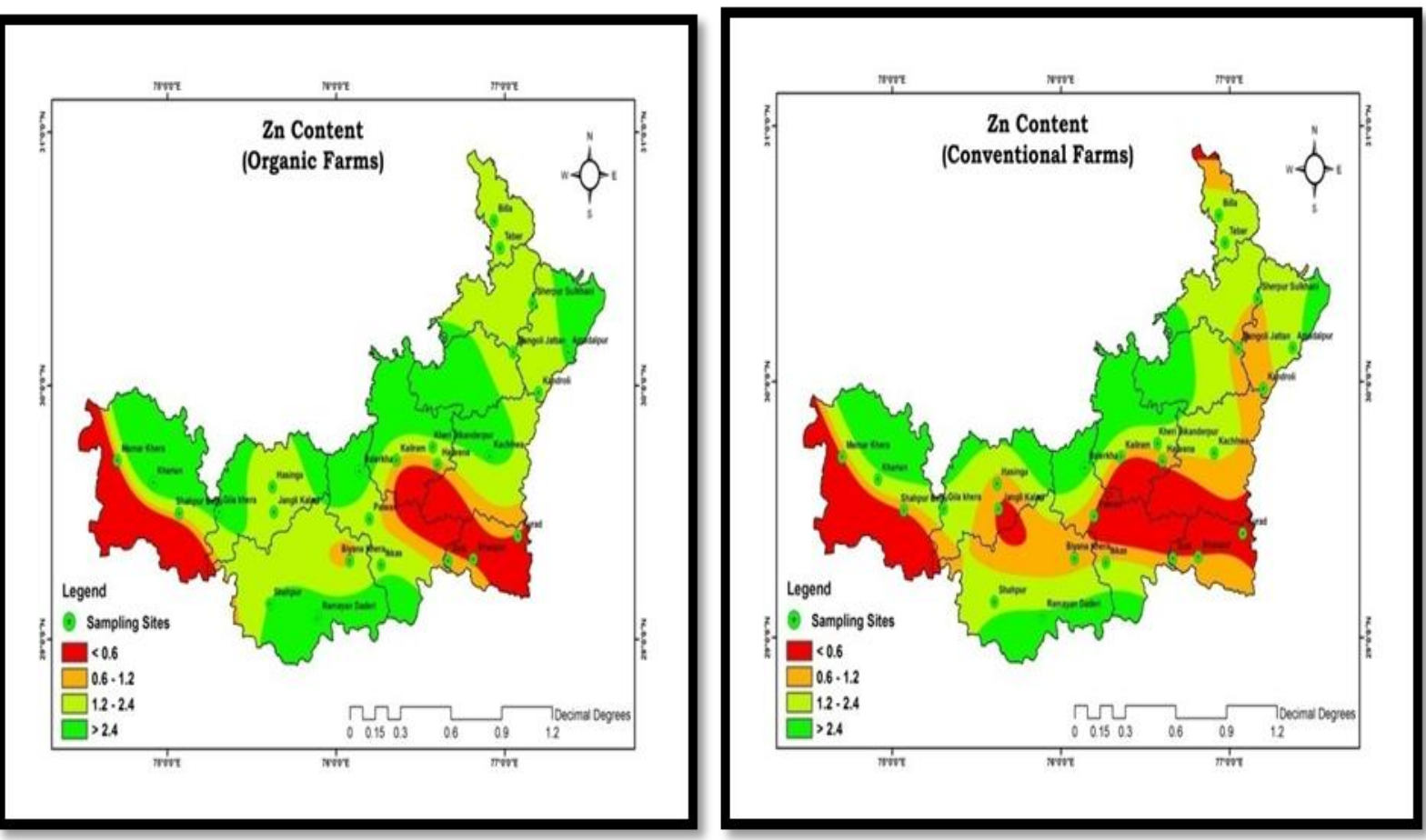

Fig.3 The spatial variability map of Fe concentration in soils under organic and conventional farming systems at different locations of Haryana
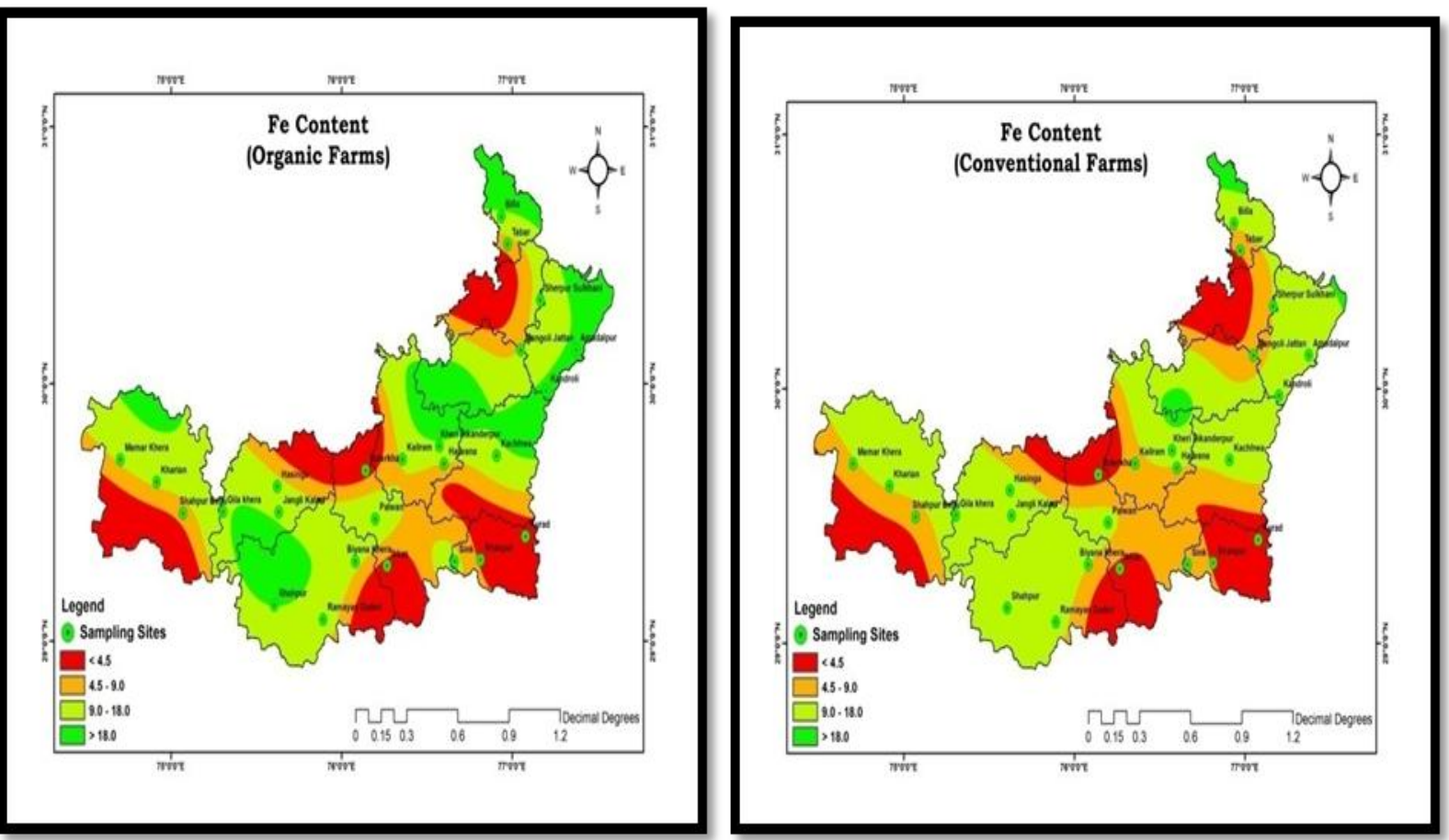
Fig.4 The spatial variability map of $\mathrm{Cu}$ concentration in soils under organic and conventional farming systems at different locations of Haryana
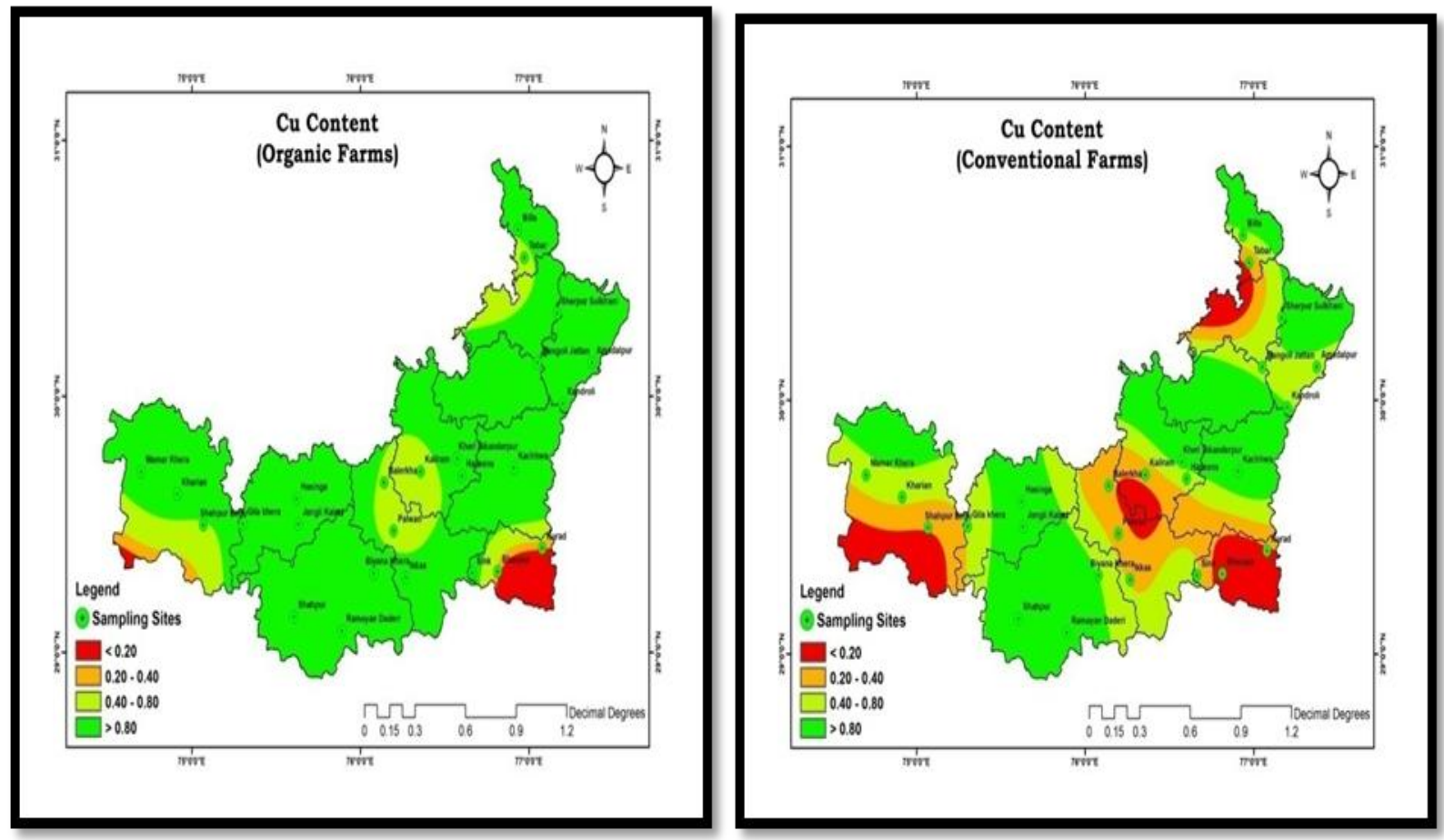

Fig.5 The spatial variability map of Mn concentration in soils under organic and conventional farming systems at different locations of Haryana
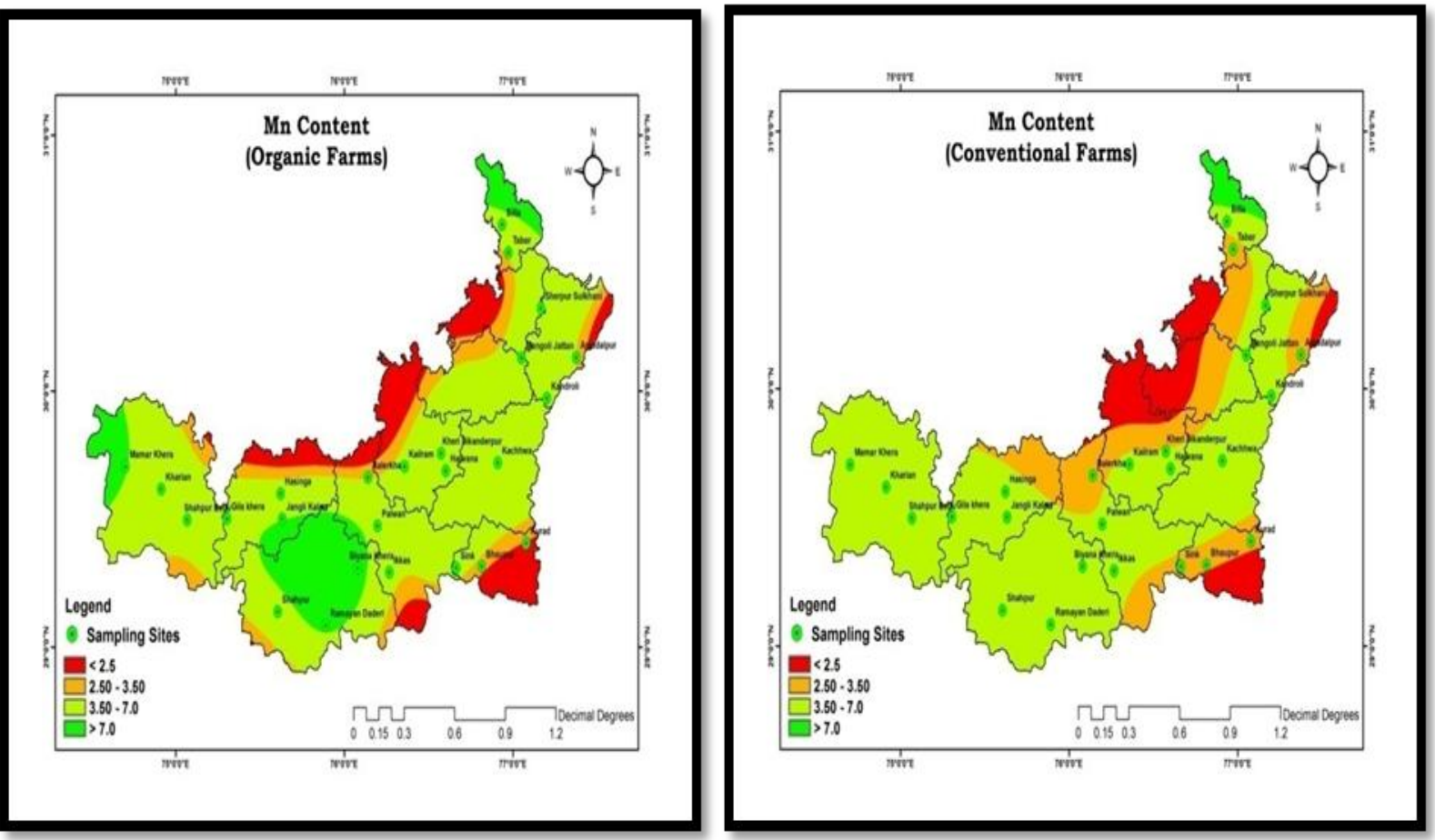
Fig.6 The relationship of $\mathrm{Zn}(\mathrm{a}), \mathrm{Fe}(\mathrm{b}), \mathrm{Cu}(\mathrm{c})$ and $\mathrm{Mn}(\mathrm{d})$ in soils under organic and conventional farming systems

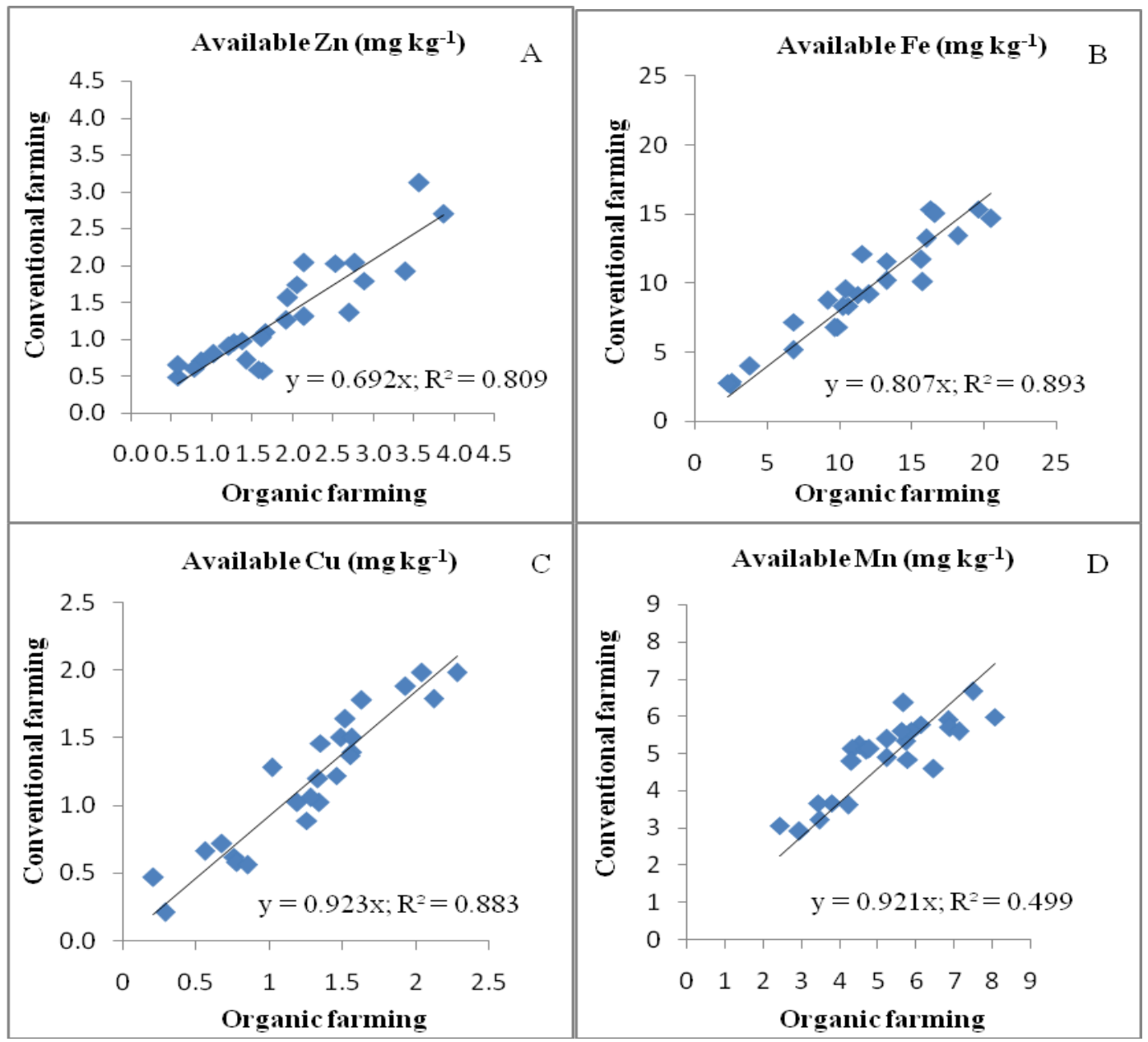

A significant increase in available zinc, iron, copper and manganese content in soils was also observed upon conversion of conventional farming to organic farming at different locations (Tables 2 and 3). Long-term organic manure application increases the organic matter in soil and the mobility of $\mathrm{Cu}, \mathrm{Fe}$ and $\mathrm{Mn}$ in the soil decreases because organic matter act as a chelating agent and their availability in long term basis increases. These elements show high affinity to organic matter and as a result they form stable bonds. The content of $\mathrm{Zn}$ in soil increases under the influence of organic matter, because this element forms labile organomineral complexes (Behera et al., 2011). Herencia et al., (2007) reported that organic farming resulted in higher $\mathrm{Fe}$ and $\mathrm{Zn}$. The available $\mathrm{Mn}$ and especially $\mathrm{Cu}$ values did not show significant differences. Likewise, organic farming with legumes and organic amendments (i.e., manure) often increases micronutrients concentrations and biological activity (Pelosi et al., 2015). For example, in eastern Nebraska, organic matter, $\mathrm{Ca}, \mathrm{K}, \mathrm{Mg}$, and $\mathrm{Zn}$ concentrations increased with organic farming (Wortman et al., 2011). The available Zn (Fig. 6a), Fe (Fig. 6b), Cu (Fig. 6c) and Mn (Fig. 6d) of soils plotted for organic farming against adjoining soils under conventional farming (intercept set at zero) also showed clearly that organic farming is very helpful in increasing available $\mathrm{Zn}(\mathrm{y}=0.692 \mathrm{x}), \mathrm{Fe}(\mathrm{y}=0.807 \mathrm{x}), \mathrm{Cu}$ $(\mathrm{y}=0.923 \mathrm{x})$ and $\mathrm{Mn}(\mathrm{y}=0.921 \mathrm{x})$ over conventional system in Haryana (Fig. 6). 


\section{References}

Araújo, A. S. F.; Santos, V. B., and Monteiro, R. T. R. 2008. Responses of soil microbial biomass and activity for practices of organic and conventional farming systems in Piauí state. Brazil. Eur. J. Soil Biol., 44, 225-230.

Behera, S. K., Singh, M. V., Singh, K. N., and Todwal, S. 2011. Distribution variability of total extractable zinc in cultivated acid soils of India and their relationship with some selected soil properties. Geoderma, 162, 242-250.

Bengtsson, J., Ahnström, J., and Weibull, A. C. 2005. The effects of organic agriculture on biodiversity and abundance: a metaanalysis. J. Appl. Ecol. 42, 261-269.

Bulluck, L. R., Brosius, M., Evanylo, G. K., and Ristaino, J. B. 2002. Organic and synthetic fertility amendments influence soil microbial, physical and chemical properties on organic and conventional farms. App. Soil Eco., 19, 147-160.

Burney, J. A., Davis, S. J., and Lobell, D. B. 2010. Greenhouse gas mitigation by agricultural intensification. PNAS, 107, 12052-12057.

Herencia, J. F., Ruiz, J. C., Melero, S., GarciaGalavis, P. A., and Maqueda, C. 2008b. A short- term comparison of organic $\mathrm{v}$. conventional agriculture in a silty loam soil using two organic amendments. J. of Agri. Sci., 146, 677-687.

Herencia, J. F., Ruiz, J. C., Morillo, E., Melero, S., Villaverde, J., and Maqueda, C. 2008a. The effect of organic and mineral fertilization on micronutrient availability in soil. Soil Science, 173, 69-80.

Herencia, J. F., Ruiz-porras, J. C., Melero, S., Garciagalavis, P. A., Morillo, E., and Maqueda, C. 2007. Comparison between organic and mineral fertilization for soil fertility levels, crop macronutrient concentrations and yield. Agron. J., 99, 973-983.

Human Development Report 2016. Human Development Report Office estimates based on abridged life-tables of the United Nations Department of Economic and Social Affairs (UNDESA).

Lindsay, W. L., and Norvell, W. A. 1978. Development of a DTPA soil test for zinc, iron, manganese and copper. Soil Sci. Soc. Am. J., 42, 421-28.

Mantovi, P., Bonazzi, G., Maestri, E., and Marmiroli, N. (2003). Accumulation of copper and zinc from liquid manure in agricultural soils and crop plants. Plant Soil, 250, 249-257.

Pelosi, C., Bertrand, M., Thenard, J., and Mougin, C. 2015. Earthworms in a 15 year agricultural trial. Appl. Soil Ecol., 88, 1-8.

Reganold, J. P., Andrews, P. K., Reeve, J. R., Carpenter-Boggs, L., Schadt, C. W., and Alldredge, J. R. 2010. Fruit and soil quality of organic and conventional strawberry agroecosystems. PLOS ONE 5: e12346.

Stockdale, E. A., Lampkin, N. H., Hovi, M., Keatinge, R., Lennartsson, E. K. M., Macdonald, D. W., Padel, S., Tattersall, F. H., Wolfe, M. S., and Watson, C.A. 2001. Agronomic and environmental implications of organic farming systems. Adv. in Agron., 70, 261-327.

Vandermer, J. 1995. The ecological basis of alternative agriculture. Ann. Rev. Ecol. Sys., 26, 201-224.

Wortman, S. E., Galusha, T. D., Mason, S. C., and Francis, C. A. 2011. Soil fertility and crop yields in long-term organic and conventional cropping systems in eastern Nebraska. Renew. Agric. Food Syst., 27, 200-216.

\section{How to cite this article:}

Hardeep Singh Sheoran, V.K. Phogat, Rita Dahiya, Subha Dhull and Ridham Kakar. 2018. Comparative Effect of Organic and Conventional Farming Practices on Micronutrient Content in Different Textured Soils of Haryana, India. Int.J.Curr.Microbiol.App.Sci. 7(04): 3399-3407. doi: https://doi.org/10.20546/ijcmas.2018.704.384 